\title{
Research on Beijing Total Logistics Demand Prediction Based on Grey Prediction Model
}

\author{
Jie Zhu, Hong Zhang, Li Zhou \\ School of Information, Beijing Wuzi University, Beijing, China
}

Email address:

dr.yuwenjunxian@gmail.com (Hong Zhang)

To cite this article:

Jie Zhu, Hong Zhang, Li Zhou. Research on Beijing Total Logistics Demand Prediction Based on Grey Prediction Model. American Journal of Theoretical and Applied Statistics. Vol. 4, No. 3, 2015, pp. 211-222. doi: 10.11648/j.ajtas.20150403.28

\begin{abstract}
As an important part of regional logistics demand forecasting in logistics system planning, in order to develop regional logistics development policy, planning and construction of logistics infrastructure, provide the basis for the necessary for analysis of the logistics market development trend. Due to the development of China's logistics industry is still in its infancy stage, various statistical data of logistics demand forecast needs is not complete, in the limited sample data, how to make a reasonable demand forecast for regional logistics has become a very important research topic. Beijing as Chinese political economic center, is the domestic cargo turnover, and an important hub for import and export, As the core of the Bohai Sea Economic Circle, Beijing in the regional economic development as a transport hub and logistics channel plays a more and more important role, therefore, should be on the Beijing logistics demand forecast analysis. This paper analyzes the present situation of Beijing logistics development, starting from the total economic output, economic structure, economic location and other aspects, basic economic situation of Beijing is analyzed. From the transportation infrastructure construction present situation, the current status of development of logistics industry, logistics enterprises are analyzed in terms of status and problems of Beijing logistics development; then further analysis of Beijing logistics development environment, all of these indicate that it is very necessary for Beijing logistics demand forecast. Using the econometric model to analyze and forecast the total demand analysis of Beijing logistics, discusses the influencing factors of Beijing logistics demand, thus the construction of index system of logistics demand forecast, and selects freight, freight turnover as a quantitative index to measure the total quantity of logistics demand, using the Eviews model and the analysis, obtains the Beijing logistics demand presents the fast growth to the situation in the future five years.
\end{abstract}

Keywords: Logistics Demand Forecasting, Econometric Model, The Grey Prediction Model

\section{Introduction}

Modern logistics is the process of industrialization in the most economical and reasonable integrated service mode as well as an important part of the modern economy, with the rapid progress of modern science and technology high speed development and the world economy, the rapid development in the global scope. In general, the level of development of the logistics industry is an important symbol to measure the comprehensive economic strength of a country and region, is a national and regional economic development of the basic industries and artery. Under the background of global economic integration, how to use the strategy planning of regional logistics system, improve the service level of the regional logistics, reduce logistics costs, improve logistics investment environment, from the single enterprise logistics rationalization to regional logistics rationalization over, realize the rational development of high levels of logistics, is the inevitable requirement of the sustainable development of regional economy. Analysis on logistics demand forecasting is one of the key problems to be solved in the layout and construction of the logistics planning. Analysis of logistics demand forecast is accurate and reasonable, determines the success of logistics planning, and then influence the development speed of regional economy. Therefore, analysis of the establishment of scientific and reasonable prediction model, based on the qualitative and quantitative analysis of logistics demand forecast, on the development of regional logistics development policy, to determine the scale of logistics infrastructure, logistics analysis of the market trend, which has important significance for more sustainable and healthy development of logistics industry. 


\section{Beijing Logistics Development Status and Environmental Analysis}

\subsection{The Economic Situation in Beijing Province}

From the Beijing statistical yearbook 2014: 2009-2013 GDP data as shown in figure 2-1:

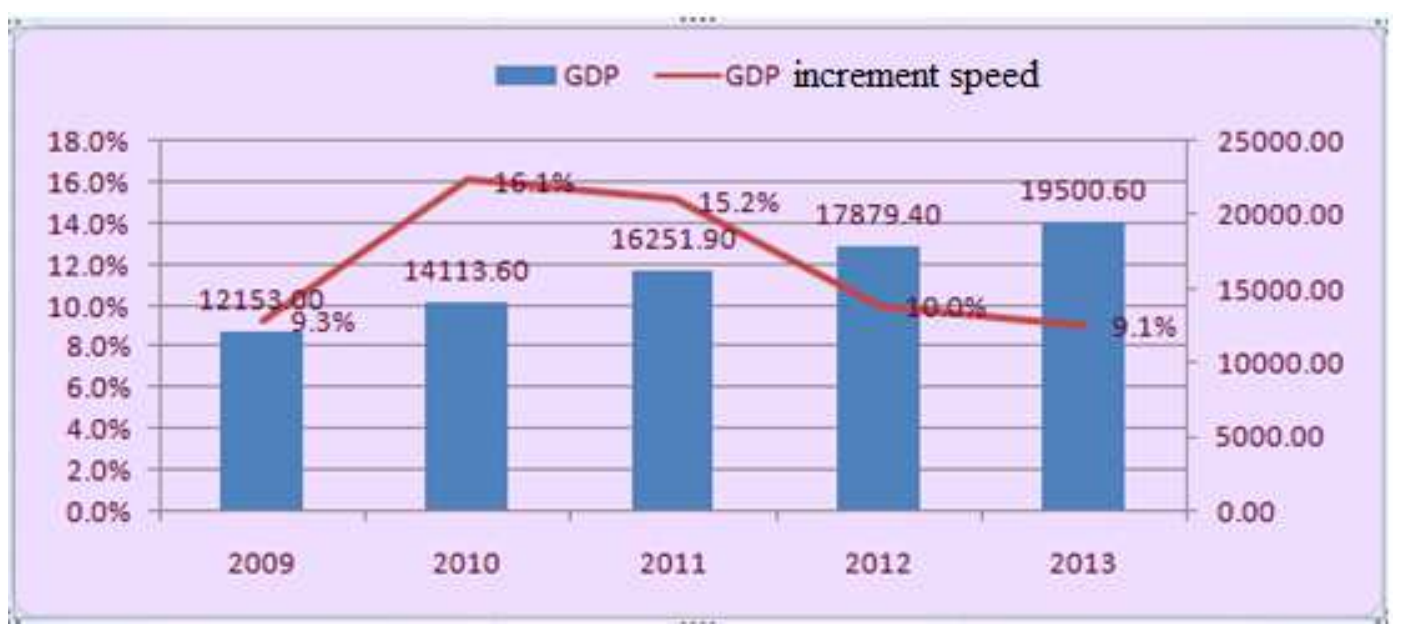

Figure 2-1. Beijing 2009-2013 GDP and growth rate.

We can be seen from figure 2-1, 2009-2013 Beijing economy maintained rapid and healthy development of the stable growth of GDP, but declining growth rate since 2010, Beijing gradually began to slow economic growth, but due to the lowest growth rate is still $9.1 \%$ of 2010 and 2011, economic growth rate above $15 \%$, shows that the quality of economic operation is still in Beijing to further improve. Due to the influence of the financial crisis in 2008 , only $9.3 \%$ growth in 2009, quick recovery reached $16.1 \%$ in 2010. 2009 gross domestic product (GDP) of $\$ 1.2153$ trillion, 2013 gross domestic product (GDP) reached 1.95006 trillion yuan, close to 2 trillion, five years to $60 \%$, suggesting that Beijing economy growth is rapid; the stability of the national economy is more and more strong.

Economic growth in 2013, in the industry, the first industry in GDP is 16.18 billion yuan, up $7.7 \%$ from a year earlier. The second industry's GDP totaled 435.23 billion yuan, up 7.2\%; the tertiary industry GDP totaled 1.49865 trillion yuan, up $9.6 \%$ from a year earlier. Primary industry, secondary industry and tertiary industry GDP accounted for the proportion of GDP of $0.83 \%, 22.32 \%$ and $76.85 \%$ respectively; Primary industry, secondary industry and tertiary industry contribution rate to economic growth of $0.72 \%, 18.07 \%$ and $81.21 \%$ respectively.

In 2013, foreign economic, Beijing import and export of goods totaled $\$ 429.942$ billion, compared with 5.31\% growth in 2012. Among them, the exports of $\$ 63.098$ billion, increased by $5.81 \%$, the goods imported for $\$ 366.844$ billion, increased by $5.27 \%$, imports accounted for $85 \%$ of the total amount of foreign trade, the total cost of the Beijing foreign economic is still mainly imports. 2013 new high-tech product export growth is strong; exports reached \$20.357 billion, an increase of $7.04 \%$. In 2013, the United States continue to Beijing's largest trade partner, bilateral trade value of $\$ 35.413$ billion, about $8.24 \%$ of the total cost of the Beijing import and export of the same period, of which only $\$ 5.712$ billion in exports to the United States, accounting for $16.13 \%$ of the total.

In recent years, Beijing's industry structure has stabilized small changes. Primary industry, secondary industry and tertiary industry GDP as a share of GDP in 2009 was $0.97 \%$, $23.50 \%$ and $75.53 \%, 0.83 \%, 22.32 \%$ and $0.83 \%$ in 2013 . In 2013 , the first industry in GDP as a share of GDP fell by $0.14 \%$ in January 2009, the second industry GDP as a share of GDP than in 2009 dropped by $1.18 \%$, the third industry in GDP as a share of GDP rose by $1.32 \%$ over 2009 .

In recent years, Beijing's industrial structure has the following characteristics: the first and second industry than slow down, gradually to the third industry, change is slow, explain the internal structure of Beijing's industry along with the continuous optimization have stabilised. The second industry as the basic is the relocation of shougang has left the central part of Beijing, and with the large number of foreign Banks, insurance companies, and into the travel company, the third industry has occupied the mainstream of the economy of Beijing, the first industry to economic crops also changed the past give priority to the traditional concept of crops. 2013 Beijing as a share of GDP reached $76.85 \%$, the tertiary industry's contribution to the economic growth of $81.21 \%$

In the first, in China, have decisive role on the economic development of Beijing. Transportation, postal and telecommunication services, wholesale and retail trade, finance, information, real estate, tourism, such as for Beijing's main industries, including finance, information sector is still growing momentum.

\subsection{The Beijing Logistics Development}

In Beijing in the traffic infrastructure construction investment calendar year are very big, with Beijing as the center of the highway, railway, the construction of the domestic and international air channel is very mature, is an important transportation hub in the domestic and international. 
Railway, Beijing is one of the center of the rail network in China, there are mainly to the beijing-kowloon railway, Kowloon, Hong Kong and Shanghai the beijing-shanghai railway, beijing-guangzhou railway, to guangzhou to Harbin jingha railway, package to baotou Beijing railway, the original to the original Beijing railway, Beijing - guilin high-speed rail, to tgo Beijing railway and to chengde Beijing railway. In terms of international rail transport, to Russia from city to city, the north Korean capital, Pyongyang, the Mongolian capital of ulan bator, and go to the Vietnamese capital Hanoi train departure from Beijing. Aviation, Beijing capital international airport, is the world's largest airport in Beijing almost all domestic and international flights at Beijing capital international airport dock and take off. The passenger throughput in 2012 reached 2012 person-time, came second in the world, second only to the Atlanta airport. Road, at the end of 2013, the Beijing municipal road mileage of 21673 kilometers, an increase of $182 \mathrm{~km}$; Among them, the highway mileage of 923 kilometers, the urban road mileage of $6295 \mathrm{~km}$, an increase of 24 kilometers. In recent years, Beijing transportation of fixed assets in the fluctuating, in 2013, the district transportation investment in fixed assets of 64.45 billion yuan, reduced by $6.67 \%$ over the previous year, show that Beijing's traffic construction has been mature and stable.

Beijing social logistics total is 7.22986 trillion yuan in 2013, compared with $2012,6.58511$ trillion yuan, increased by $9.8 \%$, and the logistics business income also increased from $\$ 2012$ in 210.44 billion to 2013 of 226.76 billion yuan, increasing $7.8 \%$. In 2013 Beijing logistics staff 489000 people, compared with 2012 in 519000 decreased by $5.8 \%, 5.6 \%$ of the city's tertiary industry practitioners, was down more than $0.6 \%$ in 2012. Reduce workers, and total logistics rising, the logistics industry in Beijing is constantly optimized and the trend of rapid development.

Beijing logistics also has many problems; however, the first is the explosive growth in the number of motor vehicles, vehicle ownership in Beijing in 2013 to 5.437 million vehicles, including 4.265 million units of private cars. Second number explosive growth, while vehicles but parking facilities in Beijing have not been corresponding growth, the number of public parking space in Beijing only reached to about $15 \%$ of car ownership, and road area rate, reduce the ability of urban road microcirculation, Beijing road overall capacity is low. The last major administrative, financial, hospital, school, business, and entertainment venues and other urban public service facilities are mostly concentrated in the areas of the city, causing the city high density of population, commerce, building, this led directly to the traffic density, accounts for only $6 \%$ of the urban area within the second, but $30 \%$ of the concentration of the motor vehicle traffic in the city.

\section{Beijing Total Logistics Demand Forecast}

This chapter analysis the factors that affect the demand for logistics in Beijing, and based on the principles of logistics demand forecasting index selection choose freight turnover and total freight volume is a measure of Beijing logistics demand indicators, establishing econometric model to predict total logistics demand, and get the general development situation of Beijing logistics demand.

\subsection{The Factors Influencing Beijing Logistics Demand Analysis}

Logistics demand affected by various factors in the process of social and economic activities and constantly changing. By analysis the influencing factors of logistics demand of Beijing in the previous chapter including economic factors, policy factors, resource factors, etc., this section mainly affect Beijing logistics demand analysis of economic factors.

(1) the economy level

Regional logistics demand is the decisive factor is the scale and level of regional economic development, but also the driving force of regional logistics demand. Logistics demand and regional economy there is a strong positive correlation between, to make the total level is high, the economic growth speed, requires the production of materials, semi-finished products and finished goods circulation faster, so the logistics demand is bigger and bigger, drive the rapid development of logistics industry. Therefore, economic development level of the logistics industry is developed, Beijing has been in high speed development of economy, driving the development of logistics industry high speed, so logistics demand is also growing.

(2) of the industrial structure

Regional differences of industrial structure affects the regional logistics demand, industrial developed area, the demand for industrial logistics, give priority to with agriculture, forestry and animal husbandry area of logistics demand quantity but low value. Due to the high speed development of economy in our country, also gradually by industrial structure is given priority to with agriculture and industry to give priority to in order to service transition, the change of industrial structure with the proliferation of logistics demand. Beijing is already relatively mature stage of industrialization, the main logistics demand is circulation processing, packaging and logistics demand of high value-added information service. At present, the need to rely on railway and highway transportation from Beijing area is transferred to a large number of grain and other agricultural products, in the Beijing area is given priority to with transportation, warehousing, logistics demand demand is big value is small. Need to import aquatic products, fruit and other economic fruit wood products outside, with road transportation is given priority to, because these products are almost all perishable, so logistics demand for rapid, efficient as its requirements. In Beijing's industrial structure, deep processing and finishing products than the major, namely the high value-added products for the final consumer services than major, so Beijing will be a lot of output high value-added products. Beijing postal, transportation and warehousing development level is much higher than the national level, the third industry, such as the financial, real estate development 
mature, but because our country logistics data statistics system is not very completely, therefore the retail sales of consumer goods through to the analysis of the third industry logistics needs.

(3) the level of consumption

Consumption level influences the scale of logistics demand and the flow is affected by the level of consumption, consumption habits of different, can make the variety of goods, quantity, cause company producing goods changes, resulting in the change of the logistics demand. Logistics demand increased with the increase of consumption level; With the loss of the level of consumption.

(4) the internal and external trade

Internal and external trade is an important part of logistics demand, with the rapid development of Beijing economy, the gradual increase in consumer demand, rapidly developed for wholesale and retail business. Beijing is much higher than the national average of wholesale and retail sales, and favorable traffic condition makes the internal and external trade has important influence on the impact logistics demand.

(5) the whole society fixed asset investment

Logistics demand is also affected by the whole society fixed asset investment, with the continued development of Beijing economy, as well as the important position in the bohai economic circle of Beijing, Beijing will continue to rapid construction of infrastructure, while the flow of construction materials will bring logistics demand increase.

\subsection{Beijing Logistics Demand Forecasting Index Research}

Index selection is the key step in the implementation of logistics demand forecasting, in order to make scientific and reasonable forecast results, it is necessary to set up the index selection principle. This article in the index selection based on the following principles

(1) the absolute quantity and relative quantity of complementary principle

Absolute reflects the level of tears in a certain period, the size and the size of the level of development, and can't reflect

The condition of the same period of economic development. Relative quantity is the ratio of absolute quantity and level of development, can reflect the conditions of economic development, the change law of demand, combine absolute quantity and relative quantity to use, can play out their respective merits.

(2) the principle of maneuverability

Because the data of the logistics industry in China is not perfect enough, so some important data cannot be obtained. So when choosing predictor selection should be able to access data index.

(3) the principle of unification of weights and measures

Due to the logistics demand of content is very rich, shall be measured by unified unit of measurement. With quantitative unit value as logistics demand, is undoubtedly the most can reflect the change of logistics demand.

(4) the principle of relevance

Predictors and the stronger the explain the correlation between indicators, results will be more reasonable and credible.

(5) the principle of relative independence

Logistics demand indicators and economic indicators to some extent, has a strong inner relation and alternative. If use these indicators to directly without filtered to forecast, may lead to the final conclusions differ with the actual situation is rather large. Therefore, for the relevant indicators when the choice, should choose relatively independent indicators.

Indicators are divided into two categories: regional logistics demand analysis, the regional logistics demand quality indexes and logistics demand quantity indexes. The former reflects the regional logistics demand structure, such as time, efficiency, cost, etc., which reflects the scale of logistics demand, including freight, freight turnover social total logistics cost, etc. But only freight volume and quantity of our country has a complete statistics and other related logistics indicators are not authoritative public statistics and statistical method, and in the logistics demand forecasting, through put of the history of general use to predict the future demand of logistics, and the change of traffic basic can reflect the change of the through put, through put in academia and no clear definition, so in this paper, based on the operational principle to choose freight volume and freight turnover, two indicators to measure the total logistics demand.

This paper selects two indexes of Beijing comprehensive freight volume and freight turnover to measure the scale of logistics demand. The freight volume is the number of actual displacement reflects the number of goods, transportation of finished goods transport, freight turnover quantity is multiplied by the number of kilometers of cargo transport, reflecting the labor intensity of the same amount of goods have different displacement. Two can be used to reflect the freight demand to a certain extent, and the freight transportation demand reflects the changes of logistics demand. So this paper will be based on the two predictions, to explore the changes of Western Beijing logistics demand. And through the front impact on economic factors of Beijing logistics demand analysis, selected the following indicators as explanatory index analysis and prediction of Beijing logistics demand: GDP of Beijing reflects the total economy (GDP); reflect the industrial structure of Beijing first, second, and third of GDP; reflect the Beijing foreign trade and international trade the total retail sales of Beijing; Beijing investment in fixed assets reflect the social infrastructure; as well as indicators of the level of consumption of per capita income in Beijing.

\subsection{Beijing Logistics Demand Forecasting Based on Econometric Model}

Econometric forecast model is to forecast target related economic factors and predict the relationship between the target with the approximate function relation between, using sample data to estimate the model parameters and error inspection. Only parameter estimation and error check through the model can be used for prediction. Regression analysis is a useful method of econometric model, this article will also take a regression analysis model is established. 
In addition, because the regression prediction in economic issues, to consider too many factors influence, resulting in the presence of many independent variable, the regression equation is easily affected by multicollinearity. At the same time, the regression coefficient estimates is not stable, the regression coefficient variance with multiple linear increase and accelerate growth, resulting in a highly significant regression equation, regression coefficient does not pass the significance test, stepwise regression method is the most commonly used method to eliminate the multicolinearity. In this paper, Eviews is used for data statistics and analysis, the existence of multicollinearity diagnosis equation, in eliminating multicollinearity, the re establishment of the regression equation.

Based on the above analysis, choose the data of $1986-2013$ explanatory variables and explanatory variables of the sample observations are as shown in table 3-1.

Table 3-1. Beijing logistics demand and the main economic indicators (1986-2013).

\begin{tabular}{|c|c|c|c|c|c|c|c|c|c|c|}
\hline & $\begin{array}{l}\text { Freight } \\
\text { volume } \\
\text { (million } \\
\text { tons) }\end{array}$ & $\begin{array}{l}\text { Cargo } \\
\text { turnover } \\
\text { (million } \\
\text { km) }\end{array}$ & $\begin{array}{l}\text { GDP } \\
(100 \\
\text { million } \\
\text { yuan) }\end{array}$ & $\begin{array}{l}\text { The total } \\
\text { output value } \\
\text { of the first } \\
\text { industry (100 } \\
\text { million yuan) }\end{array}$ & $\begin{array}{l}\text { The total } \\
\text { output value } \\
\text { of the second } \\
\text { industry (100 } \\
\text { million yuan) }\end{array}$ & $\begin{array}{l}\text { The total } \\
\text { output value } \\
\text { of the third } \\
\text { industry (100 } \\
\text { million yuan) }\end{array}$ & $\begin{array}{l}\text { Total retail } \\
\text { sales of } \\
\text { social } \\
\text { consumer } \\
\text { goods (100 } \\
\text { million } \\
\text { yuan) } \\
\end{array}$ & $\begin{array}{l}\text { The total } \\
\text { amount } \\
\text { of } \\
\text { foreign } \\
\text { trade } \\
\text { (US } \\
\text { Sbillion) }\end{array}$ & $\begin{array}{l}\text { Total } \\
\text { investment } \\
\text { in fixed } \\
\text { assets (100 } \\
\text { million } \\
\text { yuan) }\end{array}$ & $\begin{array}{l}\text { The per } \\
\text { capita } \\
\text { income } \\
\text { (yuan) }\end{array}$ \\
\hline years & $\mathrm{Y}$ & $\mathrm{Z}$ & $\mathrm{X} 1$ & $\mathrm{X} 2$ & $\mathrm{X} 3$ & $\mathrm{X} 4$ & X5 & $\mathrm{X} 6$ & $\mathrm{X} 7$ & $\mathrm{x} 8$ \\
\hline 1987 & & 279.26 & 326.80 & 24.30 & 182.60 & 119.90 & 188.90 & 267.05 & 136.20 & 1413.2 \\
\hline 1988 & & 288.73 & 410.20 & 37.10 & 221.30 & 151.80 & 256.00 & 298.86 & 163.00 & 1767.7 \\
\hline 1989 & & 276.57 & 456.00 & 38.50 & 252.20 & 165.30 & 294.80 & 286.15 & 139.50 & 1899.6 \\
\hline 1990 & & 268.82 & 500.80 & 43.90 & 262.40 & 194.50 & 345.10 & 236.45 & 179.20 & 2067.3 \\
\hline 1991 & & 279.97 & 598.90 & 45.80 & 291.50 & 261.60 & 408.30 & 242.41 & 192.00 & 2359.9 \\
\hline 1992 & & 293.87 & 709.10 & 49.10 & 345.90 & 314.10 & 503.00 & 249.82 & 266.00 & 2813.1 \\
\hline 1993 & & 314.35 & 886.20 & 53.70 & 419.60 & 412.90 & 611.20 & 279.17 & 410.40 & 3935.4 \\
\hline 1995 & & 323.10 & 1507.70 & 73.50 & 645.80 & 788.40 & 950.40 & 370.35 & 841.50 & 6748.7 \\
\hline 1996 & & 317.62 & 1789.20 & 75.00 & 714.70 & 999.50 & 1061.60 & 293.18 & 876.90 & 7945.8 \\
\hline 1997 & & 312.91 & 2077.10 & 77.20 & 781.80 & 1218.10 & 1208.50 & 303.89 & 961.20 & 8741.7 \\
\hline 1998 & & 284.67 & 2377.20 & 77.90 & 840.60 & 1458.70 & 1373.60 & 305.06 & 1155.60 & 10098.2 \\
\hline 1999 & & 283.89 & 2678.80 & 78.40 & 907.30 & 1693.10 & 1509.30 & 343.60 & 1170.60 & 10654.8 \\
\hline 2000 & & 299.64 & 3161.70 & 79.30 & 1033.30 & 2049.10 & 1658.70 & 494.00 & 1297.40 & 12560.3 \\
\hline 2001 & & 315.98 & 3708.00 & 80.80 & 1142.40 & 2484.80 & 1831.40 & 514.98 & 1530.50 & 13768.8 \\
\hline 2002 & & 340.55 & 4315.00 & 82.40 & 1250.00 & 2982.60 & 2005.20 & 525.05 & 1814.30 & 13253.3 \\
\hline 2003 & 18569 & 362.08 & 5007.20 & 84.10 & 1487.20 & 3435.90 & 2296.90 & 685.00 & 2157.10 & 14959.3 \\
\hline 2004 & 18954 & 402.28 & 6033.20 & 87.40 & 1853.60 & 4092.20 & 2626.60 & 945.76 & 2528.30 & 17116.5 \\
\hline 2005 & 19653 & 457.74 & 6969.50 & 88.70 & 2026.50 & 4854.30 & 2911.70 & 1255.06 & 2827.20 & 19533.3 \\
\hline 2006 & 20304 & 423.12 & 8117.80 & 88.80 & 2191.40 & 5837.60 & 3295.30 & 1580.37 & 3371.50 & 22417.0 \\
\hline 2007 & 20770 & 449.04 & 9846.80 & 101.30 & 2509.40 & 7236.10 & 3835.20 & 1930.00 & 3966.60 & 24576.0 \\
\hline 2008 & 21885 & 454.22 & 11115.00 & 112.80 & 2626.40 & 8375.80 & 4645.50 & 2716.93 & 3848.50 & 27678.0 \\
\hline 2009 & 22017 & 441.23 & 12153.00 & 118.30 & 2855.50 & 9179.20 & 5309.90 & 2147.91 & 4858.40 & 30674.0 \\
\hline 2010 & 23712 & 513.66 & 14113.60 & 124.40 & 3388.40 & 10600.80 & 6229.30 & 3016.61 & 5493.50 & 33360.0 \\
\hline 2013 & 28294 & 680.91 & 19500.60 & 161.80 & 4352.30 & 14986.50 & 8375.10 & 4299.42 & 7032.20 & 45274.0 \\
\hline
\end{tabular}

Data source: Beijing statistical yearbook 2014, annual report on transport development in Beijing city in 2008

As 2007 begins, the highway freight volume in Beijing only to calculate the operating freight, the freight statistics07 years ago can no longer be used, on the table in the 2003-2006 data from the annual report of the traffic development of Beijing city in 2008 by the adjustment of the data, not before 2003 adjusted data released.

Table 3-1 in the data correlation analysis, as shown in table 3-2,3-3.

Table 3-2. The correlation coefficient matrix and freight volume of each index.

\begin{tabular}{|c|c|c|c|c|c|c|c|c|c|}
\hline & $\mathrm{X} 1$ & $\mathrm{X} 2$ & $\mathbf{X 3}$ & $\mathrm{X} 4$ & X5 & X6 & $\mathbf{X} 7$ & X8 & $\mathbf{Y}$ \\
\hline $\mathrm{X} 1$ & 1 & 0.9897461 & 0.9973072 & 0.9998508 & 0.9971163 & 0.9858368 & 0.9939379 & 0.9982257 & 0.979051 \\
\hline $\mathrm{X} 2$ & 0.9897461 & 1 & 0.9834717 & 0.9903246 & 0.9925697 & 0.9702476 & 0.9776977 & 0.9884687 & 0.9756019 \\
\hline $\mathrm{X} 3$ & 0.9973072 & 0.9834717 & 1 & 0.9958932 & 0.9941427 & 0.9826185 & 0.9939543 & 0.9945576 & 0.9800217 \\
\hline $\mathrm{X} 4$ & 0.9998508 & 0.9903246 & 0.9958932 & 1 & 0.9969979 & 0.9858623 & 0.9931851 & 0.9983085 & 0.9779948 \\
\hline X5 & 0.9971163 & 0.9925697 & 0.9941427 & 0.9969979 & 1 & 0.9785186 & 0.9921697 & 0.9956074 & 0.9777364 \\
\hline X6 & 0.9858368 & 0.9702476 & 0.9826185 & 0.9858623 & 0.9785186 & 1 & 0.9656458 & 0.9791951 & 0.9777566 \\
\hline $\mathrm{X} 7$ & 0.9939379 & 0.9776977 & 0.9939543 & 0.9931851 & 0.9921697 & 0.9656458 & 1 & 0.9936121 & 0.964338 \\
\hline X8 & 0.9982257 & 0.9884687 & 0.9945576 & 0.9983085 & 0.9956074 & 0.9791951 & 0.9936121 & 1 & 0.9729113 \\
\hline $\mathrm{Y}$ & 0.979051 & 0.9756019 & 0.9800217 & 0.9779948 & 0.9777364 & 0.9777566 & 0.964338 & 0.9729113 & 1 \\
\hline
\end{tabular}


Table 3-3. The correlation coefficient matrix of freight turnover and each index.

\begin{tabular}{llllllllll}
\hline & $\mathbf{X 1}$ & $\mathbf{X 2}$ & $\mathbf{X 3}$ & $\mathbf{X 4}$ & $\mathbf{X 5}$ & $\mathbf{X 6}$ & $\mathbf{X 7}$ & $\mathbf{X 8}$ & $\mathbf{Z}$ \\
\hline X1 & 1 & 0.9397515 & 0.9957859 & 0.9996244 & 0.998018 & 0.9829407 & 0.9967726 & 0.9928041 & 0.9754114 \\
X2 & 0.9397515 & 1 & 0.9530361 & 0.9336214 & 0.9511862 & 0.8900702 & 0.9479746 & 0.9648424 & 0.9130788 \\
X3 & 0.9957859 & 0.9530361 & 1 & 0.992907 & 0.9937391 & 0.9666044 & 0.9981332 & 0.9968717 & 0.9722575 \\
X4 & 0.9996244 & 0.9336214 & 0.992907 & 1 & 0.9975591 & 0.9862713 & 0.9947432 & 0.9898561 & 0.9748036 \\
X5 & 0.998018 & 0.9511862 & 0.9937391 & 0.9975591 & 1 & 0.9789544 & 0.9950984 & 0.9933461 & 0.9714232 \\
X6 & 0.9829407 & 0.8900702 & 0.9666044 & 0.9862713 & 0.9789544 & 1 & 0.9676923 & 0.9588247 & 0.9730993 \\
X7 & 0.9967726 & 0.9479746 & 0.9981332 & 0.9947432 & 0.9950984 & 0.9676923 & 1 & 0.9956024 & 0.9684364 \\
X8 & 0.9928041 & 0.9648424 & 0.9968717 & 0.9898561 & 0.9933461 & 0.9588247 & 0.9956024 & 1 & 0.960083 \\
Z & 0.9754114 & 0.9130788 & 0.9722575 & 0.9748036 & 0.9714232 & 0.9730993 & 0.9684364 & 0.960083 & 1 \\
\hline
\end{tabular}

Table 3-2, 3-3, showed that there is a strong linear correlation between the freight volume and freight turnover quantity and the choice of the economic variables to establish multiple linear regression model. But the linear correlation between the explanatory variables is also very strong, indicate that there are serious multicollinearity. So the effect of eliminating multicollinearity stepwise regression method, a regression model. According to 3-1data, the effect of eliminating multicollinearity stepwise regression method, first used the freight turnover quantity and each index regression, as shown in table 3-4.

Table 3-4. Freight turnover (Z) and the explanatory variables in regression results.

\begin{tabular}{llllllll}
\hline & X1 & X2 & X3 & X4 & X5 & X6 & X7 \\
\hline $\mathrm{R}^{\wedge} 2$ & 0.951427 & 0.833713 & 0.945285 & 0.950242 & 0.943663 & 0.9469922 & 0.937869 \\
Coefficient & 0.019676 & 3.015046 & 0.089641 & 0.025318 & 0.047233 & 0.088626 \\
t-Statistic & 22.56726 & 11.41736 & 21.19401 & 22.28294 & 20.86885 & 21.53711 & 0.053489 \\
Prob & 0 & 0 & 0 & 0 & 0 & 0.008691 & 0 \\
\hline
\end{tabular}

Table 3-4 shows the relationship between $\mathrm{Z}$ and the explanatory variables are very high, and the correlation coefficient $\mathrm{X} 1$ is 0.951427 , and the regression coefficient is positive, in line with the economic significance. So Z,X1 and other explanatory variables for regression, as shown in table 3-5.

Table 3-5. Freight turnover volume (Z), the results of X1 regression and the explanatory variables Abstract.

\begin{tabular}{|c|c|c|c|c|c|c|c|}
\hline & X1 X2 & X1 X3 & X1 X4 & X1 X5 & X1 X6 & X1 X7 & X1 X8 \\
\hline $\mathrm{R}^{\wedge} 2$ & 0.951536 & 0.951536 & 0.951505 & 0.952494 & 0.957496 & 0.9537 & 0.956242 \\
\hline Coefficient & -0.100746 & 0.010486 & -0.008348 & -0.02523 & 0.038575 & -0.0328 & -0.005246 \\
\hline t-Statistic & -0.23689 & 0.236899 & -0.200011 & -0.74909 & 1.889282 & -1.107763 & -1.658582 \\
\hline Prob & 0.8147 & 0.8147 & 0.8431 & 0.4608 & 0.0705 & 0.2785 & 0.1097 \\
\hline X1-Coefficient & 0.020255 & 0.017392 & 0.026158 & 0.030123 & 0.011278 & 0.031617 & 0.031286 \\
\hline X1-t-Statistic & 7.79609 & 1.795794 & 0.806884 & 2.155707 & 1.889282 & 2.923702 & 4.438592 \\
\hline X1-Prob & 0 & 0.0846 & 0.4273 & 0.0409 & 0.0705 & 0.0072 & 0.0002 \\
\hline
\end{tabular}

Table 3-6 shows the Z, X1 and other indicators of the results of the regression fit although increased, but the explanatory variables are not through the significant test, and regression coefficient is negative, does not meet the economic significance. Taking into account the correlation coefficient $\mathrm{Z}$ and the explanatory variables are very high, so the removal of $\mathrm{X} 1$, and $\mathrm{Z}$ and other explanatory variables in regression, $\mathrm{Z}$ and $\mathrm{X} 4$ correlation coefficient of regression, Z, X4 and other explanatory variables, as shown in table 3-6.

Table 3-6. Freight turnover volume (Z), the results of X4 regression and the explanatory variables Abstract.

\begin{tabular}{lllllll}
\hline & X4 X2 & X4 X3 & X4 X5 & X4 X6 & X4 X7 \\
\hline $\mathrm{R}^{\wedge} 2$ & 0.950311 & 0.951592 & 0.950448 & 0.955244 & 0.950389 \\
Coefficient & 0.076698 & 0.028491 & -0.009982 & 0.039005 & -0.006546 \\
t-Statistic & 7.659275 & 0.834933 & -0.322 & 1.671457 & -0.27244 \\
Prob & 0.8534 & 0.4117 & 0.7501 & 0.1071 & -0.002167 \\
X4-Coefficient & 0.024755 & 0.017349 & 0.030737 & 0.014348 & 0.7875 \\
X4-t-Statistic & 7.659275 & 1.804816 & 1.850104 & 2.155962 & 0.02838 & 2.511822 \\
X4-Prob & 0 & 0.0832 & 0.0762 & 0.0409 & 0.0314773 \\
\hline
\end{tabular}

Table 3-6, regression results of Z, X4 and Z, X1, X4 and Z, thus eliminating, $\mathrm{X} 6$ and other explanatory variables in 
Table 3-7. Freight turnover volume (Z), the results of X6 regression and the explanatory variables Abstract.

\begin{tabular}{lllll}
\hline & X6 X2 & X6 X3 & X6 X5 & X6 X7 \\
\hline $\mathrm{R}^{\wedge} 2$ & 0.957532 & 0.96218 & 0.955412 & 0.9582 \\
Coefficient & 0.746187 & 0.044439 & 0.021952 & 0.023263 \\
t-Statistic & 2.499187 & 3.175804 & 2.18171 & 0.955995 \\
Prob & 0.0194 & 0.0039 & 0.0387 & 2.597118 \\
X6-Coefficient & 0.070308 & 0.046194 & 0.048372 & 0.0155 \\
X6-t-Statistic & 8.537579 & 3.341891 & 2.566553 & 0.051505 \\
X6-Prob & 0 & 0.0026 & 0.0166 & 3.487053 \\
\hline
\end{tabular}

Table 3-7 shows the regression results of $\mathrm{Z}, \mathrm{X} 6$ and the explanatory variables of goodness of fit were improved, and the variable passed significant test, regression coefficients were positive, with Z, X6, X3 optimal. Taking into account the goodness of fit of little difference with each group results in $3-7$, then add other explanatory variables in regression, the results such as schedule A. Table 3-4 shows the results of goodness of fit, although improved, but the variables are not through the significant test of regression coefficient, some results are negative, does not meet the economic significance. Therefore the result of stepwise regression model based on Z, $\mathrm{X} 6, \mathrm{X} 3$, as shown in table 3-8.

Table 3-8. To the total amount of foreign trade (X6), the total output value of the second industry (X3) as the explanatory variable model.

\begin{tabular}{llll}
\hline Dependent Variable: $\mathbf{Z}$ & & & \\
\hline Method: Least Squares & & & \\
Date: 04/29/15 Time: $16: 35$ & & & \\
Sample: 1986 2013 & & & \\
Included observations: 28 & Coefficient & Std. Error & 32.07128 \\
C & 256.2928 & 7.991349 & 3.341891 \\
X6 & 0.046194 & 0.013823 & 3.175804 \\
X3 & 0.044439 & 0.013993 & 0.0000 \\
R-squared & 0.962180 & Mean dependent var & 0.0026 \\
Adjusted R-squared & 0.959154 & S.D. dependent var & 0.0039 \\
S.E. of regression & 23.92750 & Akaike info criterion & 374.5421 \\
Sum squared resid & 14313.13 & Schwarz criterion & 118.3925 \\
Log likelihood & -127.0445 & Hannan-Quinn criter. & 9.288891 \\
F-statistic & 318.0123 & Durbin-Watson stat & 9.431627 \\
Prob(F-statistic) & 0.000000 & & 9.332527 \\
\hline
\end{tabular}

Results: (1) the coefficients are positive, size appropriate, in line with economic significance that Beijing foreign trade import and export volume increased by 100000000 yuan, turnover of freight traffic will increase 0.046194tons kilometers; the second industry output value of each increase of L billion yuan, freight turnover will increase 0.044439 tons kilometers. The determination coefficient R2 $=0.96218$ (2) model, showed that the total value of the explanatory variables of Beijing foreign trade import and export volume and the second industry in Beijing to explain the ability of Beijing freight turnover volume $96.22 \%$, model fitting is good. (3) the variance test $F$ value significance probability was 0 , the overall effect is significant regression model, explanatory variables and theconstant term is significant by test. (4) the D.W. statistic value is $\mathrm{DW}=0.79597$, the test level is 0.05 under the condition of test, from the DW table look up the corresponding critical values of $\mathrm{dL}=1.2551, \mathrm{dU}=1.5601$, and $0<\mathrm{DW}<\mathrm{dL}$, the presence of first-order autocorrelation model, iterative method was used to eliminate the autocorrelation model, as shown in table 3-9.

At this point, $\mathrm{DW}=1.620289, \quad \mathrm{dU}<\mathrm{DW}<4-\mathrm{Dl}$, $1.5601<1.620289<2.7449$, the models are first order autocorrelation, and passed the test.

Table 3-9. Iteration method to eliminate the first-order autocorrelation.

\begin{tabular}{|c|c|c|c|c|}
\hline \multicolumn{5}{|c|}{ Dependent Variable: $Z$} \\
\hline \multicolumn{5}{|c|}{ Method: Least Squares } \\
\hline \multicolumn{5}{|c|}{ Date: 04/29/15 Time: $16: 41$} \\
\hline \multicolumn{5}{|c|}{ Sample (adjusted): 19872013} \\
\hline \multicolumn{5}{|c|}{ Included observations: 27 after adjustments } \\
\hline \multicolumn{5}{|c|}{ Convergence achieved after 7 iterations } \\
\hline & Coefficient & Std. Error & t-Statistic & Prob. \\
\hline $\mathrm{C}$ & 255.2887 & 17.39753 & 14.67385 & 0.0000 \\
\hline $\mathrm{X} 6$ & 0.046133 & 0.017066 & 2.703205 & 0.0127 \\
\hline $\mathrm{X} 3$ & 0.047274 & 0.019304 & 2.448942 & 0.0224 \\
\hline $\mathrm{AR}(1)$ & 0.612560 & 0.176020 & 3.480060 & 0.0020 \\
\hline R-squared & 0.975047 & Mean depe & & 378.8970 \\
\hline Adjusted R-squared & 0.971793 & S.D. depen & & 118.3404 \\
\hline S.E. of regression & 19.87530 & Akaike inf & & 8.952786 \\
\hline
\end{tabular}




\begin{tabular}{llll}
\hline Dependent Variable: $\mathbf{Z}$ & & \\
\hline Sum squared resid & 9085.635 & Schwarz criterion \\
Log likelihood & -116.8626 & Hannan-Quinn criter. & 9.144762 \\
F-statistic & 299.5824 & Durbin-Watson stat & 9.009871 \\
Prob(F-statistic) & 0.000000 & & \\
Inverted AR Roots & .61 & & \\
\hline
\end{tabular}

The regression model:

$$
Z=255.2887+0.047274 X 3+0.046133 \times 6+[A R(1)=0.612560]
$$

Similarly, using stepwise regression method to Y, X2, X6 results of optimal results, such as schedule $B$ each step regression, because of adding second variables all the equations of the explanatory variables are not through the significant test, taking into account the economic significance of selected variables, such as the 3-10 equation, the fitting the best goodness, significant variables are relatively optimal.

Table 3-10. To the total amount of foreign trade (X6) and the first industry total output value (X2) as the explanatory variable model.

\begin{tabular}{|c|c|c|c|c|}
\hline \multicolumn{5}{|c|}{ Dependent Variable: Y } \\
\hline \multicolumn{5}{|c|}{ Method: Least Squares } \\
\hline \multicolumn{5}{|c|}{ Date: $04 / 29 / 15$ Time: $16: 46$} \\
\hline \multicolumn{5}{|c|}{ Sample: 20032013} \\
\hline \multicolumn{5}{|c|}{ Included observations: 11} \\
\hline & Coefficient & Std. Error & $\mathrm{t}$-Statistic & Prob. \\
\hline $\mathrm{C}$ & 11839.26 & 2355.078 & 5.027120 & 0.0010 \\
\hline $\mathrm{X} 6$ & 1.527893 & 0.745801 & 2.048661 & 0.0747 \\
\hline $\mathrm{X} 2$ & 62.87661 & 35.52883 & 1.769735 & 0.1147 \\
\hline R-squared & 0.968385 & \multicolumn{2}{|c|}{ Mean dependent var } & 22696.09 \\
\hline Adjusted R-squared & 0.960481 & \multicolumn{2}{|c|}{ S.D. dependent var } & 3686.622 \\
\hline S.E. of regression & 732.8751 & \multicolumn{2}{|c|}{ Akaike info criterion } & 16.25883 \\
\hline Sum squared resid & 4296847. & \multicolumn{2}{|c|}{ Schwarz criterion } & 16.36735 \\
\hline Log likelihood & -86.42356 & \multicolumn{2}{|c|}{ Hannan-Quinn criter. } & 16.19042 \\
\hline F-statistic & 122.5224 & \multicolumn{2}{|c|}{ Durbin-Watson stat } & 1.263502 \\
\hline Prob(F-statistic) & 0.000001 & & & \\
\hline
\end{tabular}

Results: (1) the coefficients are positive, size appropriate, in line with economic significance that Beijing foreign trade import and export volume increased by 100000000 yuan, freight volume will increase by 15278.93 tons, total output value of the primary industry grew 1 billion yuan, freight volume will increase by 628766.1 tons; (2) the modelcoefficient of determination $\mathrm{R} 2=0.968385$ total the output value of the explanatory variable total import and export of Beijing and Beijing the first industry explanation ability to the Beijing freight volume $96.84 \%$, model fitting is good.(3) the variance test $F$ value significance probability was 0.000001 , the overall effect is significant regressionmodel; explanatory variables and the constant term was not all through the t test, but is optimal in all models; (4)due to the lack of sample size 15, can not use DW test, test using the Q statistics, as shown in Fig. 3-1, we can see that the model does not exist correlation, the ideal result through the test.

\begin{tabular}{|c|c|c|c|c|c|c|c|c|}
\hline Autocorrelati & & Partial Correl & ation & & $A C$ & PAC & Q-Stat & Prob \\
\hline$\longmapsto$ & 1 & $\longmapsto$ & I & 1 & 0.340 & 0.340 & 1.6574 & 0.198 \\
\hline I & 1 & $1 \square$ & I & 2 & -0.147 & -0.298 & 2.0014 & 0.368 \\
\hline $1 \square$ & 1 & 14 & 1 & 3 & -0.312 & -0.180 & 3.7363 & 0.291 \\
\hline$\square$ & 1 & $1 \square$ & 1 & 4 & -0.508 & -0.459 & 9.0106 & 0.061 \\
\hline 1 므 & 1 & b & 1 & 5 & -0.142 & 0.113 & 9.4945 & 0.091 \\
\hline 2 & 1 & 무 & 1 & 6 & 0.112 & -0.162 & 9.8562 & 0.131 \\
\hline 1 & I & $1 \square$ & I & 7 & 0.021 & -0.249 & 9.8722 & 0.196 \\
\hline 1 & । & 무 & 1 & 8 & 0.069 & -0.156 & 10.101 & 0.258 \\
\hline 2 & 1 & 1 & I & 9 & 0.092 & 0.028 & 10.712 & 0.296 \\
\hline I & 1 & 다 & I & 10 & -0.026 & -0.187 & 10.812 & 0.372 \\
\hline
\end{tabular}

Figure 3-1. Q statistic test. 
The regression model:

$$
\mathrm{Y}=11839.26+62.87661 \mathrm{X} 2+1.527893 \mathrm{X} 6
$$

Freight volume prediction results: by Eviews using the exponential smoothing forecast on the total output value of foreign trade in 2015-2019 and the first industry, the results are shown in table 3-11,3-12.

Table 3-11. Smoothing process variables X2.

\begin{tabular}{|c|c|c|}
\hline \multicolumn{3}{|c|}{ Date: 04/29/15 Time: 17:01 } \\
\hline \multicolumn{3}{|l|}{ Sample: 20032013} \\
\hline \multicolumn{3}{|c|}{ Included observations: 11} \\
\hline \multicolumn{3}{|c|}{ Method: Holt-Winters No Seasonal } \\
\hline \multicolumn{3}{|l|}{ Original Series: X2 } \\
\hline \multicolumn{3}{|l|}{ Forecast Series: X2SM } \\
\hline \multirow[t]{2}{*}{ Parameters: } & & 1.0000 \\
\hline & & 0.4100 \\
\hline \multicolumn{2}{|c|}{ Sum of Squared Residuals } & 227.2708 \\
\hline \multicolumn{2}{|c|}{ Root Mean Squared Error } & 4.545436 \\
\hline \multirow[t]{2}{*}{ End of Period Levels: } & Mean & 161.8000 \\
\hline & Trend & 11.20673 \\
\hline
\end{tabular}

Table 3-12. smoothing process variables X6.

\begin{tabular}{|c|c|c|}
\hline \multicolumn{3}{|c|}{ Date: 04/29/15 Time: $16: 59$} \\
\hline \multicolumn{3}{|c|}{ Sample: 20032013} \\
\hline \multicolumn{3}{|c|}{ Included observations: 11} \\
\hline \multicolumn{3}{|c|}{ Method: Holt-Winters No Seasonal } \\
\hline \multicolumn{3}{|c|}{ Original Series: X6 } \\
\hline \multicolumn{3}{|l|}{ Forecast Series: X6SM } \\
\hline \multirow{2}{*}{ Parameters: $\quad$ A } & & 0.2100 \\
\hline & & 0.1200 \\
\hline \multicolumn{2}{|c|}{ Sum of Squared Residuals } & 1046911. \\
\hline \multicolumn{2}{|c|}{ Root Mean Squared Error } & 308.5023 \\
\hline \multirow[t]{2}{*}{ End of Period Levels } & Mean & 4345.925 \\
\hline & Trend & 380.6104 \\
\hline
\end{tabular}

Combined with the regression model, which can forecast freight volume was 2015-2019, as shown in table 3-13.

Table 3-13. Freight volume forecasting results.

\begin{tabular}{llll}
\hline year & X2 & X6 & Y \\
\hline 2015 & 184.2135 & 5107.146 & 31225.15023 \\
2016 & 195.4202 & 5487.756 & 32511.32355 \\
2017 & 206.6269 & 5868.366 & 33797.49687 \\
2018 & 217.8337 & 6248.977 & 35083.67018 \\
2019 & 229.0404 & 6629.587 & 36369.8435 \\
\hline
\end{tabular}

The development trend of freight volume as shown in figure 3-2.

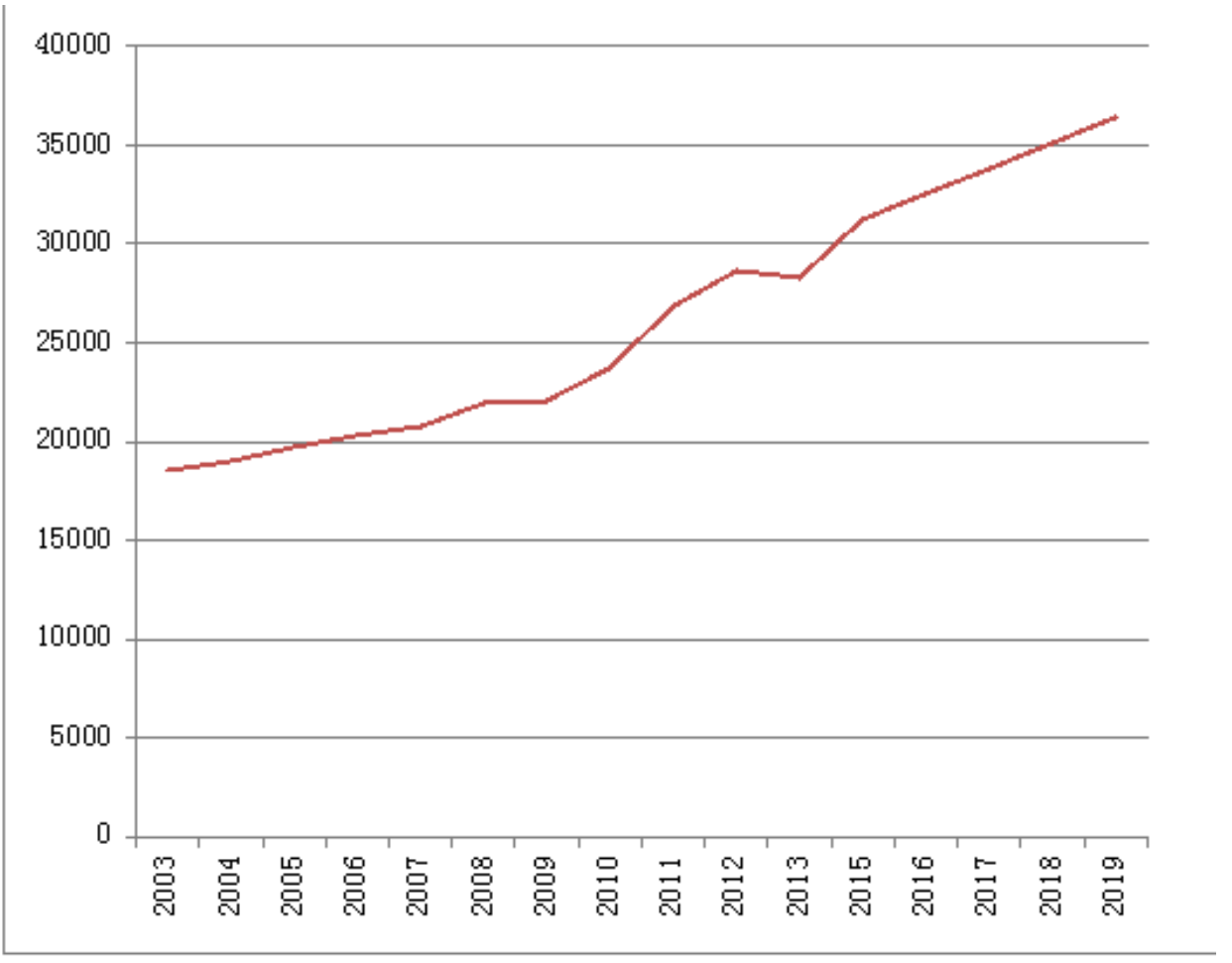

Figure 3-2. Freight development trends.

From the trend can be found, in addition to the freight volume of Beijing has a small amount of the decline in 2013, has maintained a rapid growth, especially since 2009, growth accelerated, can foresee the future freight volume will continue to maintain rapid growth, indicating that Beijing's logistics demand is more and more big, logistics enterprise development space and opportunities the broader. Beijing's rapid economic growth, foreign trade continues to expand, more and more to optimize the industrial structure, has good prospects for the development of logistics industry. As can be 
seen from the regression model of Beijing is closely related with the freight volume is the total output value of the first industry and foreign trade, and the present situation of Beijing is in line with this, more than half of Beijing's logistics are from import and export, and the grain and other agricultural products come from other provinces required, This has greatly promoted the development of logistics industry in Beijing.

Freight turnover forecasting results: by Eviews using the exponential smoothing forecast on the total output value of foreign trade and the second industry during 2015-2019, the results are as shown in table 3-14,3-15.

Table 3-14. Smoothing process variables X6.

\begin{tabular}{|c|c|c|}
\hline \multicolumn{3}{|c|}{ Date: 04/29/15 Time: 17:07 } \\
\hline \multicolumn{3}{|l|}{ Sample: 19862013} \\
\hline \multicolumn{3}{|c|}{ Included observations: 28} \\
\hline \multicolumn{3}{|c|}{ Method: Holt-Winters No Seasonal } \\
\hline \multicolumn{3}{|l|}{ Original Series: X6 } \\
\hline \multicolumn{3}{|l|}{ Forecast Series: X6SM } \\
\hline \multirow[t]{2}{*}{ Parameters: } & & 0.2800 \\
\hline & & 1.0000 \\
\hline \multicolumn{2}{|c|}{ Sum of Squared Residuals } & 1551849. \\
\hline \multicolumn{2}{|c|}{ Root Mean Squared Error } & 235.4213 \\
\hline \multirow[t]{2}{*}{ End of Period Levels: } & Mean & 4480.027 \\
\hline & Trend & 445.4406 \\
\hline
\end{tabular}

Table 3-15. Smoothing process variables $X 3$.

\begin{tabular}{|c|c|c|}
\hline \multicolumn{3}{|l|}{ Date: 04/29/15 Time: 17:09 } \\
\hline \multicolumn{3}{|l|}{ Sample: 19862013} \\
\hline \multicolumn{3}{|l|}{ Included observations: 28} \\
\hline \multicolumn{3}{|c|}{ Method: Holt-Winters No Seasonal } \\
\hline \multicolumn{3}{|l|}{ Original Series: X3 } \\
\hline \multicolumn{3}{|l|}{ Forecast Series: X3SM } \\
\hline \multirow[t]{2}{*}{ Parameters: } & & 1.0000 \\
\hline & & 0.4000 \\
\hline \multicolumn{2}{|l|}{ Sum of Squared Residuals } & 227095.5 \\
\hline \multicolumn{2}{|l|}{ Root Mean Squared Error } & 90.05861 \\
\hline \multirow[t]{2}{*}{ End of Period Levels: } & Mean & 4352.300 \\
\hline & Trend & 316.1843 \\
\hline
\end{tabular}

Forecast of freight turnover results are shown in table 3-16

Table 3-16. Freight volume forecast.

\begin{tabular}{llll}
\hline year & X3 & X6 & Z \\
\hline 2015 & 4984.668665 & 5370.9083 & 738.710039 \\
2016 & 5300.852997 & 5816.3489 & 774.206848 \\
2017 & 5617.03733 & 6261.7895 & 809.703658 \\
2018 & 5933.221662 & 6707.2301 & 845.200467 \\
2019 & 6249.405995 & 7152.67071 & 880.697277 \\
\hline
\end{tabular}
3-3.

The development trend of freight volume as shown in figure

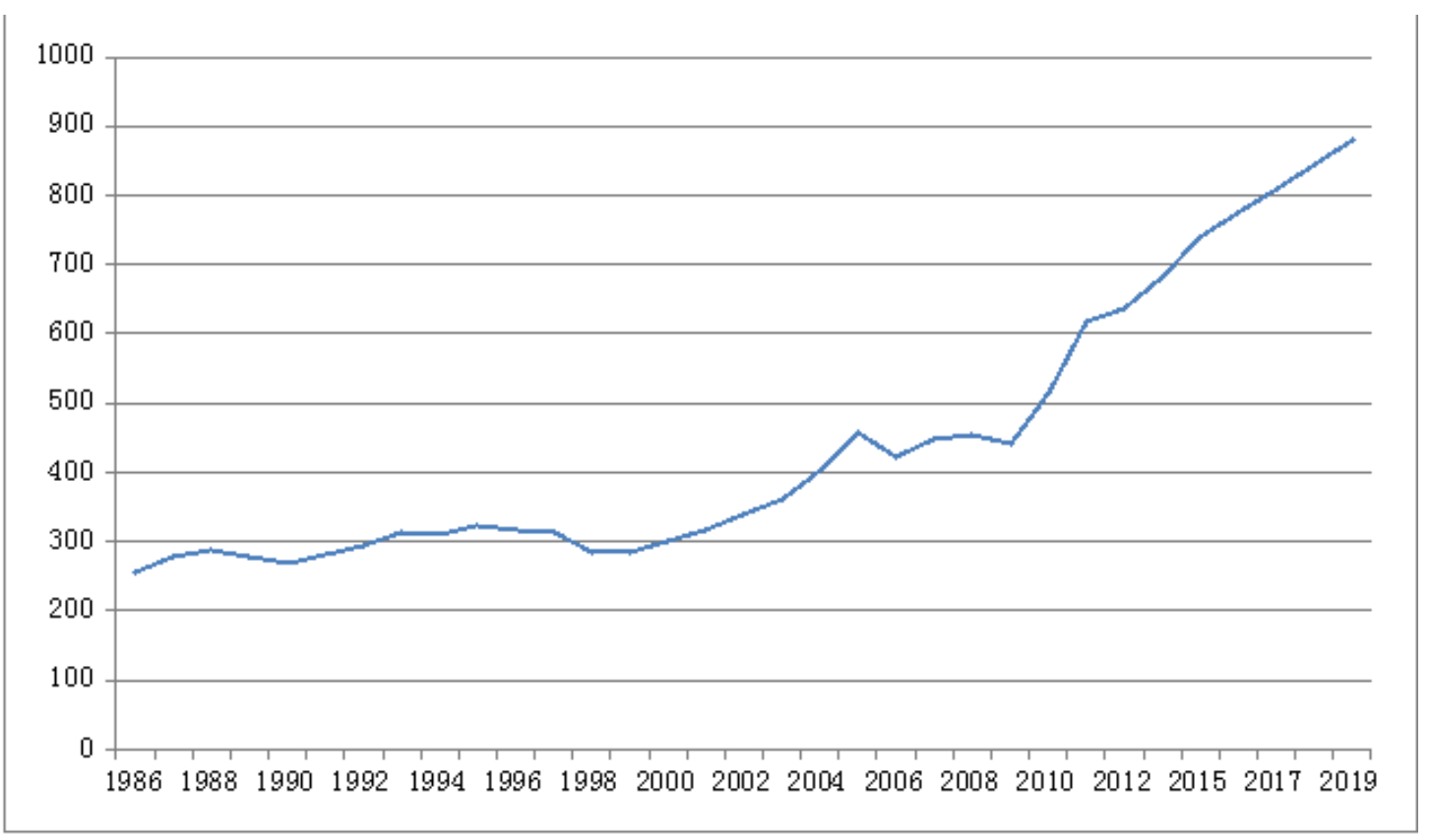

Figure 3-3. Freight turnover trend of development.

As can be seen from the figure, freight turnover of Beijing's rapid growth beginning in 2009, this also indicates that the future will continue to maintain high growth, brought about the development of logistics industry in Beijing. Beijing's rapid economic growth, foreign trade continues to expand, more and more to optimize the industrial structure has good prospects for the development of logistics industry. As can be seen from the regression model of Beijing is closely related with the freight volume is the total output value of the second industry and foreign trade, and the present situation of Beijing is in line with the Beijing, a large number of import and export demand, and finished product output to other provinces, has brought rapid growth of logistics volume, and promote the rapid development of the logistics industry in Beijing health. 
Table 3-17. The regression results of freight turnover quantity Z, X6 and other explanatory variables in the abstract.

\begin{tabular}{|c|c|c|c|c|c|c|}
\hline Model & X6 X3 X1 & X6 X3 X2 & X6 X3 X4 & X6 X3 X5 & X6 X3 X7 & X6 X3 X8 \\
\hline $\mathrm{R}^{\wedge} 2$ & 0.966829 & 0.962247 & 0.966876 & 0.964453 & 0.965528 & 0.969833 \\
\hline X6-Coefficient & 0.088633 & 0.047471 & 0.089264 & 0.060407 & 0.05006 & 0.038684 \\
\hline X3-Coefficient & 0.140575 & 0.040591 & 0.109493 & 0.08156 & 0.129366 & 0.156441 \\
\hline Coefficient & -0.030247 & 0.097653 & -0.030414 & -0.02708 & -0.053242 & -0.010308 \\
\hline X6-t-Statistic & 3.326398 & 3.084954 & 3.327744 & 3.383614 & 3.652739 & 2.984375 \\
\hline X3-t-Statistic & 2.59863 & 1.731298 & 2.903109 & 2.470633 & 2.258705 & 3.317913 \\
\hline t-Statistic & -1.834087 & 0.206851 & -1.844551 & -1.23869 & -1.526698 & -2.467417 \\
\hline X3-Prob & 0.0158 & 0.0962 & 0.0078 & 0.021 & 0.0333 & 0.0029 \\
\hline \multirow[t]{2}{*}{ Prob } & 0.0791 & 0.8379 & 0.0775 & 0.2274 & 0.1399 & 0.0211 \\
\hline & X6 X7 X1 & X6 X7 X2 & X6 X7 X4 & X6 X7 X5 & X6 X7 X8 & \\
\hline $\mathrm{R}^{\wedge} 2$ & 0.958273 & 0.959418 & 0.960412 & 0.958502 & 0.958462 & \\
\hline X6-Coefficient & 0.058204 & 0.056062 & 0.090459 & 0.05676 & 0.050342 & \\
\hline X7-Coefficient & 0.033345 & 0.014485 & 0.063527 & 0.032775 & 0.033629 & \\
\hline Coefficient & -0.005134 & 0.385003 & -0.02984 & -0.011143 & -0.001594 & \\
\hline t-Statistic & -0.205665 & 0.848927 & -1.158058 & -0.417896 & -0.388886 & \\
\hline X6-Prob & 0.1179 & 0.0016 & 0.0212 & 0.0079 & 0.0031 & \\
\hline X7-Prob & 0.51 & 0.3014 & 0.0894 & 0.1938 & 0.2442 & \\
\hline \multirow[t]{2}{*}{ Prob } & 0.8388 & 0.4043 & 0.2582 & 0.6797 & 0.7008 & \\
\hline & X6 X2 X1 & X6 X2 X4 & X6 X2 X5 & X6 X2 X8 & & \\
\hline $\mathrm{R}^{\wedge} 2$ & 0.958865 & 0.958025 & 0.957585 & 0.9577 & & \\
\hline X6-Coefficient & 0.050185 & 0.056688 & 0.066288 & 0.066379 & & \\
\hline X2-Coefficient & 0.423155 & 0.56884 & 0.658249 & 0.58754 & & \\
\hline Coefficient & 0.006321 & 0.005197 & 0.003369 & 0.000811 & & \\
\hline X6-t-Statistic & 2.067912 & 2.10005 & 2.67737 & 4.353154 & & \\
\hline X2-t-Statistic & 0.89389 & 1.260988 & 1.108933 & 0.983534 & & \\
\hline t-Statistic & 0.881958 & 0.530601 & 0.172591 & 0.308553 & & \\
\hline X6-Prob & 0.0496 & 0.0464 & 0.0132 & 0.0002 & & \\
\hline X2-Prob & 0.3803 & 0.2194 & 0.2784 & 0.3352 & & \\
\hline Prob & 0.3865 & 0.6006 & 0.8644 & 0.7603 & & \\
\hline X6-Coefficient & 0.029876 & 0.056024 & 0.05633 & & & \\
\hline X8-Coefficient & -0.001716 & 0.002645 & 0.002419 & & & \\
\hline Coefficient & 0.016969 & 0.002051 & 0.004885 & & & \\
\hline X6-t-Statistic & 0.910321 & 1.586877 & 2.403965 & & & \\
\hline X8-t-Statistic & -0.34258 & 0.648395 & 0.586221 & & & \\
\hline t-Statistic & 0.984351 & 0.101887 & 0.158344 & & & \\
\hline X6-Prob & 0.3717 & 0.1256 & 0.0243 & & & \\
\hline X8-Prob & 0.7349 & 0.5229 & 0.5632 & & & \\
\hline \multirow[t]{2}{*}{ Prob } & 0.3348 & 0.9197 & 0.8755 & & & \\
\hline & X6 X5 X1 & X6 X5 X4 & & & & \\
\hline $\mathrm{R}^{\wedge} 2$ & 0.957866 & 0.955548 & & & & \\
\hline X6-Coefficient & 0.036871 & 0.04353 & & & & \\
\hline X8-Coefficient & -0.0151 & 0.013418 & & & & \\
\hline Coefficient & 0.017901 & 0.005925 & & & & \\
\hline X6-t-Statistic & 1.749322 & 1.659375 & & & & \\
\hline X8-t-Statistic & -0.459127 & 0.405123 & & & & \\
\hline t-Statistic & 1.182397 & 0.270996 & & & & \\
\hline X6-Prob & 0.093 & 0.1101 & & & & \\
\hline X8-Prob & 0.6503 & 0.689 & & & & \\
\hline Prob & 0.2486 & 0.7887 & & & & \\
\hline
\end{tabular}

\section{Summary}

In recent years, with the continuous development of regional economy in Beijing, provides a good opportunity for the development of the logistics industry in Beijing. In order to make the logistics industry to maintain rapid development, lasting, the need for overall planning of logistics development, therefore, to carry on the forecast to the logistics demand, the paper analyzes the logistics demand forecast of Beijing, has made progress as follows:(1) analysis of the research background and research significance of logistics demand, summarizes the current situation of logistics demand in China, analyzed the present situation and development of environmental logistics development in Beijing. (2) through 
the analysis of economic impact of Beijing logistics demand, select the appropriate indicators to construct the index system of logistics demand forecast, using the econometric model to forecast the logistics demand of Beijing, the use of Eviews modeling and analysis of Beijing logistics demand, the rapid growth in the next five years the conclusion (3) using the grey prediction model to forecast the Beijing freight, freight turnover structure prediction, by calculating the freight volume in 2007-2013 years, the freight volume ratio, the establishment of GM $(1,1)$ model, the Beijing railway, highway, aviation and pipeline in the sharing rate is predicted from 2015 to 2019 , according to the results of prediction total logistics needs, calculate all kinds of freight volume in the next five years, the freight volume. From the results, the highway freight transportation and pipeline transportation of freight turnover ratio gradually increased the gradual decline in the share rate of freight, railway freight turnover, the change of civil aviation freight volume and freight turnover is not. Various modes of transport capacity load increases and decreases, the transportation structure has changed greatly, but the total logistics needs in the rapid growth.

But due to the limited level of knowledge and cognition, there exist the following problems: (1) this paper only focus on economic factors of Beijing logistics demand, logistics demand is affected by other factors, the quantitative relationship between the factors and the logistics demand and the impact of some problems, may have overlooked some important explanatory variables; (2) only predict the freight, freight turnover on the macro level, the spatial distribution of logistics demand, flow and flow without considering. (3) in the theoretical study of the definition of the material flow is different, there is no statistical data on the logistics quantity of authoritative and credible, so the transport volume forecast logistics quantity, only that the general trend of the development of logistics demand.

\section{Acknowledgements}

This paper is funded by the project of National Natural Science Fund, Logistics distribution of artificial order picking random process model analysis and research(Project number: 71371033); and funded by intelligent logistics system Beijing Key Laboratory (No.BZ0211); and funded by scientific-research bases--- Science \& Technology Innovation Platform---Modern logistics information and control technology research (Project number: PXM2015_014214_000001); and funded by 2014-2015 school year, Beijing Wuzi University, College students' scientific research and entrepreneurial action plan project (No.68); and funded by Beijing Wuzi University, Yunhe scholars program(00610303/007); and funded by Beijing Wuzi University, Management science and engineering Professional group of construction projects. (No. PXM2015_014214_000039). University Cultivation Fund
Project of 2014-Research on Congestion Model and algorithm of picking system in distribution center (0541502703); and funded by Beijing philosophy and social sciences planning project "Statistical measure and quantitative studies on the development of green logistics in Beijing "(13JGC078).

\section{References}

[1] Cai Xiaoli,Analysis and forecast of regional logistics demand. [J]; logistics technology, 2004 (12)

[2] Zhang Fengrong, Jin Junwu; the application of grey system model in the prediction of logistics amount of goods. [J]; 2003 (06) of industrial technology economy

[3] Cao Mingxia;Study on the grey incidence analysis model and its application [D]; Nanjing University of Aeronautics \& Astronautics 2007

[4] Chen Changying. Research on analysis and forecast of logistics demand in Guangxi. [D]; Wuhan University of Technology 2010

[5] Zhang Lixue; Study on the prediction method of city logistics demand [D]; Southeast University; 2006

[6] Sun Minwei, Shao Jianli; Study on the establishment of a modern logistics system of statistical indicators.[J]; 2007 (20) of modern business

[7] Gong Shusheng, Liu Kaiming; Analysis of the development situation of logistics in China.[J] China circulation economy; $2003(01)$.

[8] Chandyan; Wang Wenke; Hunan Province logistics demand forecast [A]; "two types of social construction and management of" HunanInnovation Forum [C] 2008

[9] Yang Fan; Analysis of the influence of Chinese modern logistics industry on regional economy [D]; Jilin University 2011

[10] Zhao Qilan; Wang Jia Qiong; Liu Hongzhi; analysis of the logistics development needs and potential demand; [J]; China soft science 2004

[11] Wang Xiaoyuan, Li Jun. The grey GM $(1,1)$ model is applied to Forecasting Regional Logistics Scale, Journal of Wuhan University of Technology, 2005 (06)

[12] Cai Dingping; logistics statistics [M] 2010.03

[13] Chen Yana, Ju Songdong; regional logistics demand analysis -Taking the Yangtze River Delta region of Nantong as an example [J]; Journal of Beijing Jiaotong University (SOCIAL SCIENCE EDITION) 2005 (04)

[14] Cao Juan; the discussion on the construction of modern logistics system of statistical indicators of $[\mathrm{J}]$; logistics engineering and management, 2010 (1) 